\title{
KULIAH KERJA MAHASISWA (KKM) di MASA PANDEMI COVID-19 SEBAGAI SALAH SATU BENTUK PENGABDIAN KEPADA MASYARAKAT
}

\author{
Rehulina Tarigan \\ Sistem Informasi, Universitas Banten Jaya, Jl Syech Nawawi Albantani Serang, Banten, Indonesia \\ Email: rtarigan@unbaja.ac.id
}

\begin{abstract}
The pandemic not only presents anxiety about health threats, but also the welfare of many employees due to layoffs. Some of small, medium and even large scale businesses were forced to go out of business. Universita Banten Jaya immediately responded positively to the impact that emerged in the community due to the Covid-19 pandemic by holding a Student Work Lecture with the theme "Increasing Community Productivity During the Covid 19 Period". With the Student Creativity Program scheme, students are expected to be able to actualize their ability to contribute to increasing productivity and even people's income by providing education on how to do activities while adhering to health protocols, sharing knowledge on how to make products that are needed to protect and increase endurance such as making masks from cloth, hand sanitizer from aloe vera and ginger extract balm. It is hoped that by sharing this knowledge, people can remain productive and even open new businesses in terms of manufacturing these products to improve their economy. The method used is in the form of an explanation of how to manufacture it along with the tools and materials needed for the product mentioned above. The process of making is uploaded to social media in the form of a video so that it can be accessed by the wider community. It is hoped that more and more people will remain enthusiastic, productive and even pursue the manufacturing business of the above products to improve their economy and open up new jobs.
\end{abstract}

Keywords: Pandemic; Covid 19; Student Work Lecture; Student Creativity Programs; Productivity.

\begin{abstract}
ABSTRAK
Pandemi tidak hanya menghadirkan resah tentang ancaman kesehatan, tetapi juga ancaman kesejahteraan akibat banyak karyawan terkena Pemutusan Hubungan Kerja (PHK). Beberapa usaha kecil, menengah bahkan berskala besar terpaksa gulung tikar. Universita Banten Jaya segera merespon positif akan dampak yang muncul di masyarakat akibat pandemi covid-19 dengan menyelenggarakan kegiatan Kuliah Kerja Mahasiswa (KKM) yang bertemakan "Meningkatkan Kembali Produktivitas Masyarakat di Tengah Covid 19". Dengan skema KKM Program Kreativitas Mahasiswa (KKMPKM), mahasiswa diharapkan dapat mengaktualisasikan kemampuannya untuk berkontribusi meningkatkan produktifitas bahkan pendapatan masyarakat dengan cara memberikan penyuluhan bagaimana beraktifitas dengan tetap menaati protokol kesehatan, membagikan pengetahuan cara membuat produk yang sangat dibutuhkan untuk melindungi dan meningkatkan daya tahan tubuh seperti pembuatan masker dari kain, hand sanitizer dari lidah buaya dan balsem ekstrak jahe. Dengan membagi pengetahuan ini, diharapkan masyarakat dapat tetap produktif bahkan membuka usaha baru dalam hal pembuatan produk tersebut untuk meningkatkan ekonomi mereka. Metode yang dilakukan berupa penjelasan cara pembuatan beserta alat dan bahan yang diperlukan untuk produk tersebut di atas. Proses pembuatan diunggah ke media sosial dalam bentuk video sehingga dapat diakses masyarakat luas. Diharapkan semakin banyak masyarakat yang tetap semangat, produktif bahkan menekuni usaha pembuatan produk di atas untuk meningkatkan ekonomi mereka dan membuka lapangan kerja baru.
\end{abstract}

Kata Kunci: Pandemi; Covid 19; Kuliah Kerja Mahasiswa; Program Kreativitas Mahasiswa; Produktivitas. 


\section{PENDAHULUAN}

Dalam Undang-undang Tentang Pendidikan Tinggi (Indonesia, 2012), disebutkan bahwa pengabdian kepada masyarakat merupakan kegiatan sivitas akademika dalam mengamalkan dan membudayakan ilmu pengetahuan dan teknologi untuk memajukan kesejahteraan umum dan mencerdaskan kehidupan bangsa. Program pengabdian kepada masyarakat yang dilaksanakan oleh Perguruan Tinggi (PT) adalah salah satu dari implementasi Tridharma Perguruan Tinggi. Program ini dilaksanakan dalam berbagai bentuk misalnya: pendidikan dan pelatihan masyarakat, pelayanan masyarakat dan kaji tindak dari Ilmu Pengetahuan dan Teknologi (Iptek) yang dihasilkan oleh Perguruan Tinggi. Tujuan program ini adalah menerapkan hasil-hasil Iptek untuk pemberdayaan masyarakat sehingga menghasilkan perubahan pengetahuan, keterampilan, dan sikap dari kelompok masyarakat sasaran (Noor, 2010).

Kuliah Kerja Mahasiswa (KKM) merupakan salah satu bentuk kegiatan pengabdian masyarakat oleh mahasiswa dengan pendekatan lintas keilmuan dan sektoral pada waktu dan daerah tertentu. KKM merupakan kegiatan perkuliahan dan kerja lapangan yang merupakan pengintegrasian dari pendidikan dan pengajaran serta pengabdian kepada masyarakat oleh mahasiswa secara pragmatis, berdimensi luas melalui pendekatan interdisipliner, komprehensif dan lintas sektoral. KKM merupakan mata kuliah wajib pada seluruh program studi Sarjana dan Diploma di lingkungan Universitas Banten Jaya. Inti dari mata kuliah KKM ini adalah pembelajaran sekaligus pengabdian pada masyarakat. Oleh karena itu, seluruh kegiatan yang mengandung nilai pembelajaran dan pengabdian pada masyarakat dapat diakui sebagai KKM. Kegiatankegiatan tersebut dilaksanakan dalam masa KKM pada semester berjalan (Wulansari Sisca dkk, 2020).

Program KKM di lingkungan UNBAJA dilaksanakan dengan skema KKM Program Kreativitas Mahasiswa (KKM-PKM) yang merupakan penyetaraan kegiatan dan pengakuan terhadap bidang Pengabdian kepada Masyarakat yang diselenggarakan oleh Kementerian Pendidikan dan Kebudayaan atau sebelumnya Kementerian Riset, Teknologi dan Pendidikan Tinggi Republik Indonesia (Wulansari Sisca dkk, 2020). PKM dikembangkan untuk mengantarkan mahasiswa mencapai taraf pencerahan kreativitas dan inovasi berlandaskan penguasaan sains dan teknologi serta keimanan yang tinggi. Dalam rangka mempersiapkan diri menjadi pemimpin yang cendekiawan, wirausahawan mandiri dan arif, mahasiswa diberi peluang untuk mengimplementasikan kemampuan, keahlian, sikap, tanggungjawab, membangun kerjasama tim maupun mengembangkan kemandirian melalui kegiatan yang kreatif dalam bidang ilmu yang 
ditekuni. PKM secara umum bertujuan untuk memandu mahasiswa menjadi pribadi yang (1) tahu dan taat aturan; (2) kreatif, inovatif dan (3) objektif kooperatif dalam membangun keragaman intelektua. Pada awalnya, dikenal lima jenis kegiatan yang ditawarkan dalam PKM, yaitu PKM-Penelitian (PKM-P), PKM-Kewirausahaan (PKMK), PKM-Pengabdian kepada Masyarakat (PKM-M), PKM-Penerapan Teknologi (PKM-T) dan PKM-Penulisan Ilmiah (PKM-I) (Kemendikbud, 2020). Berdasarkan hasil yang sudah didapatkan, kebanyakan mahasiswa melakukan kegiatan PKMKewirausahaan dengan tujuan untuk meningkatkan peran usaha kecil dan menengah di masyarakat. Seperti pembuatan masker dan hand sanitizer dapat dijadikan sebagai kegiatan usaha karena banyak dibutuhkan masyarakat pada saat ini. Kegiatan ini membuat masyarakat yang menekuninya menjadi tetap produktif dan dapat mengembangkan bidang usahanya.

Dalam keadaan normal atau bukan pada masa pandemi seperti sekarang ini, maka pelaksanaan kegiatan KKM biasanya berlangsung antara satu sampai dua bulan dan bertempat di daerah setingkat desa. Beberapa contoh kegiatan KKM yang dapat dilakukan mahasiswa dalam keadaan normal yaitu: menjadi relawan di daerah yang terkena bencana alam, ikut serta dalam kegiatann kerja di puskesmas, ikut serta dalam Kegiatan Belajar Mengajar (KBM) di sekolah, mengenalkan pembuatan dan pengelolaan blog atau website resmi desa dan lain sebagainya.

KKM 2020 diikuti oleh sekitar 420 mahasiswa yang dibagi menjadi tujuh belas kelompok. Setiap kelompok dibagi lagi menjadi 3 sub kelompok yang masing-masing sub kelompok akan menghasilkan satu tuisan berupa proposal mengenai hasil KKM yang mereka lakukan. Kebetulan penulis membimbing Kelompok 10 yang terdiri dari sub kelompok 10.A, 10.B dan 10.C. Pada masa pandemi covid-19 sekarang ini, kegiatan KKM berbeda dari tahun-tahun sebelumnya. Mahasiswa dibatasi untuk berkumpul baik dengan anggota kelompoknya apalagi untuk terjun secara langsung ke masyarakat. Hal ini dimaksudkan untuk mencegah terjadinya penularan infeksi covid-19 yang sudah banyak memakan korban jiwa. Oleh karena itu, pihak manajemen dan akademik Universitas Banten Jaya (UNBAJA) mengambil kebijakan bahwa KKM pada tahun 2020 tetap dilaksanakan tetapi dengan cara yang berbeda yaitu mahasiswa diminta untuk melakukan beberapa kegiatan sehingga menghasilkan luaran berupa video yang diunggah ke beberapa media sosial seperti youtube, facebook dan instagram. Selain itu mahasiswa dapat membuat artikel yang diterbitkan di media cetak baik lokal maupun nasional. Sesuai dengan luaran yang ditargetkan yaitu mengunggah video di media sosial dan menulis artikel di media cetak, maka diharapkan kegiatan KKM 2020 ini 
dapat berjalan sesuai protokol kesehatan yang sudah ditetapkan pemerintah yaitu menjaga jarak atau tidak berkumpul dalam waktu yang lama.

Adapun tema yang diusung Unbaja untuk kegiatan KKM 2020 adalah "Meningkatkan Kembali Produktivitas Masyarakat di Tengah Covid 19" (Wulansari Sisca dkk, 2020). Setiap mahasiswa diminta untuk membuat video atau artikel yang berkatian dengan tema tersebut, misalnya bagaimana menaati protokol kesehatan yang ditetapkan pemerintah untuk dapat tetap beraktifitas dan produktif di masa pandemi, bagaimana membuat produk sederhana seperti minuman herbal sehingga dapat dikonsumsi untuk meningkatkan daya tahan (imunitas) tubuh. Selain dari contoh itu, mahasiswa juga dapat mengunggah video berolah raga untuk meningkatkan imunitas tubuh dari serangan berbagai macam penyakit.

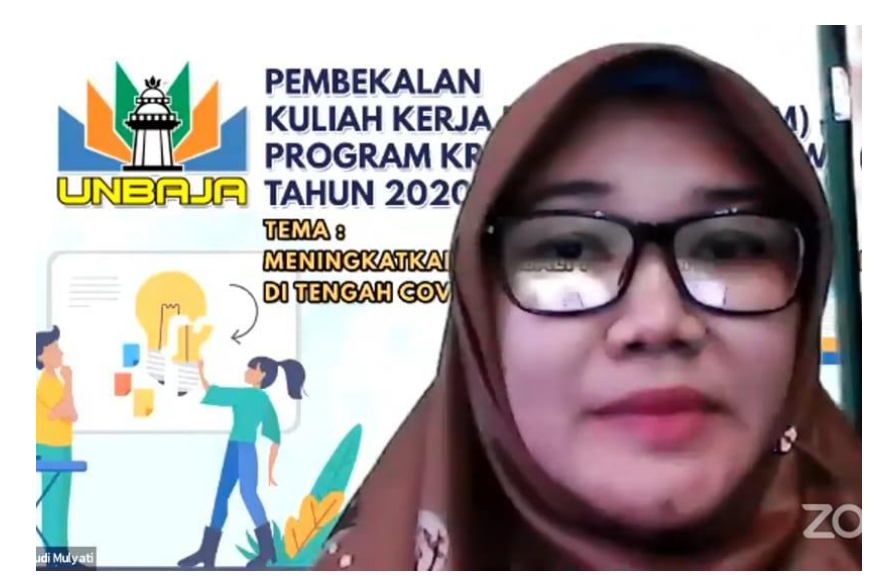

\section{Gambar 1. Pembekalan KKM oleh Ketua Pelaksana (Sisca Wulansari)}

Imunitas merupakan suatu reaksi dalam tubuh terhadap benda asing yang masuk ke dalam tubuh secara molekular atau selular. Sel yang terlibat dalam sistem imun tubuh adalah sel $\mathrm{T}$ yang dihasilkan oleh timus dan sel B yang dihasilkan oleh sumsum tulang belakang. Perkembangan dan aktivitas dari sel $\mathrm{T}$ dapat distimulasi dengan cara penambahan suatu immunomodulator (Sukmayadi et al., 2014). Immunomodulator adalah substansi yang dapat memodulasi fungsi dan aktifitas sistem imun tubuh.

Dengan mengunggah video tersebut ke beberapa media sosial, maka masyarakat luas dapat mengaksesnya dan mengambil manfaat dari video itu. Dapat dikatakan mahasiswa membagi pengetahuan yang mereka miliki kepada masyarakat, yang bagi penulis dapat disebut sebagai bagian dari kegiatan dalam melakukan pengabdian kepada masyarakat. Dari sejumlah video yang diunggah mahasiswa ke 
beberapa media sosial sebagai bagian dari Program Kreativitas Mahasiswa (PKM), maka pada artikel ini penulis akan membahas 3 hal yang dilakukan oleh mahasiswa yaitu:

1. Pembuatan balsem ekstrak jahe sebagai alternatif obat oles pereda pegal-pegal pada tubuh.

2. Membuat hand sanitizer dari bahan alami (lidah buaya).

3. Masker kain ramah lingkungan.

Kegiatan dalam pembuatan balsem ekstrak jahe, hand sanitizer dan masker ini merupakan kegiatan yang dilakukan oleh sub kelompok dalam Kelompok 10.

\section{METODE}

Sesuai dengan sub bab Pendahuluan di atas, maka pada bagian ini, penulis akan membahas tentang metode pembuatan produk beserta bahan dan alatnya untuk balsem ekstrak jahe, hand sanitizer dan masker. Selain dari metode, penulis akan membahas secara singkat mengenai masing-masing bagian, misalnya mengenai hand sanitizer dan lidah buaya, mengenai balsem dan jahe serta ulasan mengenai masker. Hal ini disebabkan pada bab Pendahuluan, penulis menguraikan pembahasan mengenai KKMPKM secara umum. Berikut ini akan dibahas metode pembuatan produk yang dilakukan oleh setiap sub kelompok pada kelompok 10.

\section{Balsem Ekstrak Jahe Sebagai Obat Oles Pereda Pegal Pada Tubuh}

Jahe mengandung zat-zat yang bermanfaat bagi manusia, diantaranya oleoresin. Sifat oleoresin jahe hasil ekstraksi sama dengan rimpang segarnya. Hal ini memungkinkan untuk dibuat menjadi produk baru berbahan dasar oleoresin jahe, misalnya balsem jahe (Pibriani, n.d.). Telah banyak dilakukan penelitian mengenai kandungan senyawa anti inflamasi dan minyak volatille pada jahe yang memiliki efek analgesik serta pereda nyeri (Alit Kurniawan, 2018). Pada kegiatan KKM ini, mahasiswa mengolah ekstrak jahe menjadi obat oles (balsem) untuk meredakan pegalpegal pada tubuh.

Dengan adanya usaha pembuatan balsam ekstrak jahe ini diharapkan mampu memanfaatkan sumber daya alam secara optimal, menghasilkan produk baru, membuka lapangan pekerjaan, meningkatkan pendapatan masyarakat, dan petani rempah khususnya. Terlebih di masa pandemi Covid-19, dengan adanya usaha ini dapat membantu para usaha kecil dan menengah dalam meningkatkan produktivitas dan meningkatkan kembali perekonomiannya. 
Alat dan Bahan

Berikut adalah alat dan bahan yang digunakan dalam proses pembuatan balsem ekstrak jahe.

Alat:

1. Wadah untuk balsem

2. Kompor

3. Panci

4. Sendok

Bahan:

1. Ekstrak jahe $(2 \mathrm{ml})$

2. Kristal menthol (3 gr)

3. Peppermint oil ( $2 \mathrm{ml})$

4. Stearic acid (6 gr)

5. Vaselin (15 gr)

\section{Cara Pembuatan:}

Proses pembuatan balsem ini adalah sebagai berikut

1. Larutkan kristal menthol dan peppermint oil.

2. Masukkan vaseline ke dalam panic

3. Didihkan dalam api sedang

4. Tambahkan ekstrak jahe, lalu masukkan stearic acid dan tunggu hingga mendidih.

5. Tambahkan larutan kristal menthol dan peppermint oil ke dalam panci tersebut, tunggu dan aduk hingga tercampur rata. 


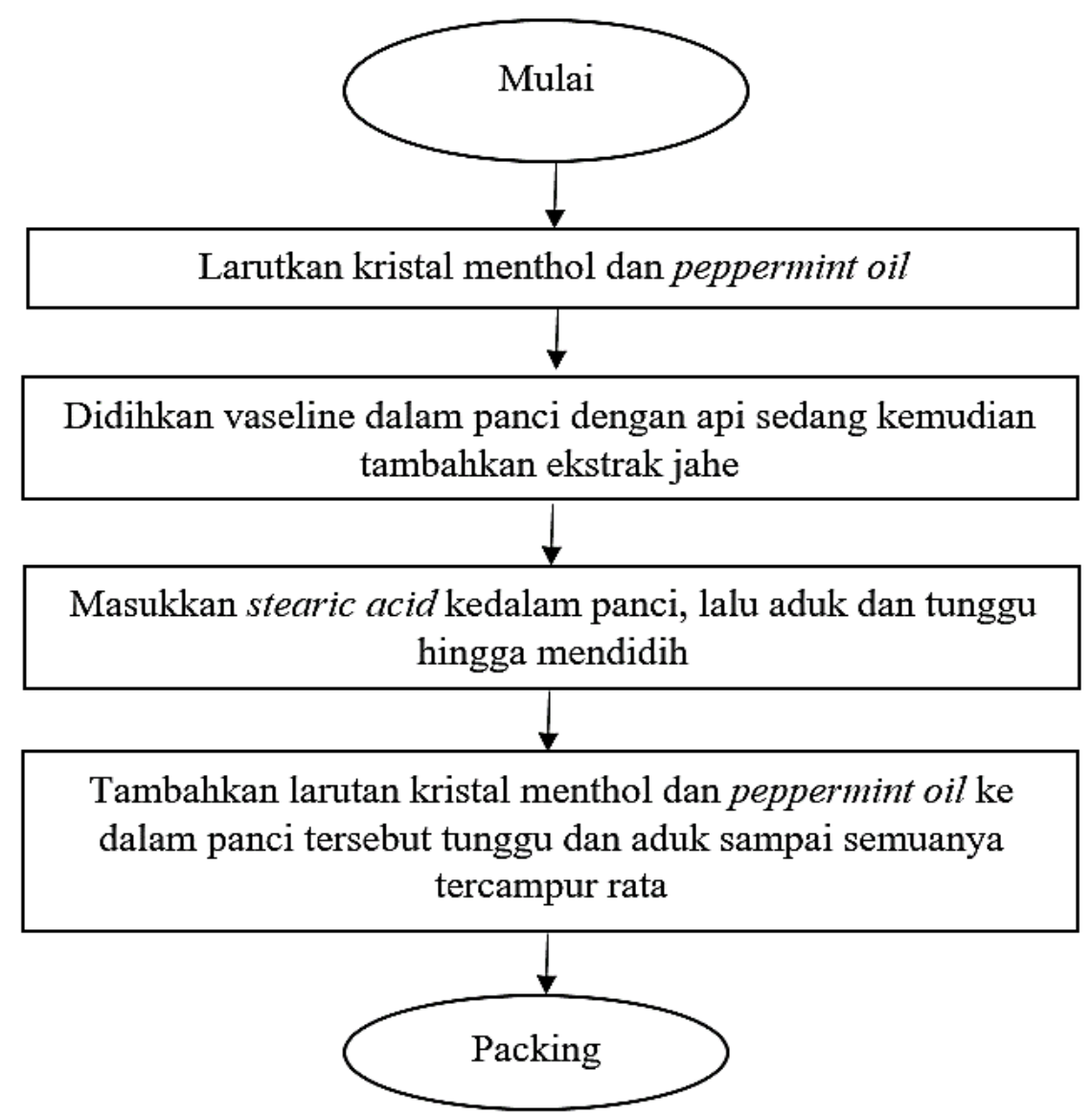

\section{Gambar 2. Diagram Proses Pembuatan Balsem Ekstrak Jahe}

\section{Membuat Hand Sanitizer dari Bahan Alami}

Setelah viral banyak kasus korban terinveksi virus corona di seluruh dunia, sekitar Maret 2020 penulis kesulitan mendapatkan hand sanitizer karena merupakan barang langka akibat banyaknya permintaan masyarakat. Diketahui bahwa salah satu cara pencegahan penularan virus tersebut adalah dengan rajin mencuci tangan menggunakan sabun atau membersihkan kuman penyakit dari tangan dengan menggunakan hand sanitizer.

Ternyata penggunaan hand sanitizer secara terus-menerus berdampak negatif, seperti yang dikemukakan oleh Gazali Solahudin (2020) bahwa jika dibiarkan terusmenerus, membuat kulit menjadi kasar dan pecah-pecah. Kulit kering dan rusak menjadi sarang bakteri penyakit dan juga meningkatkan resiko virus memasuki tubuh melalui luka di kulit. Terlepas dari dampak negatif yang ditimbulkannya, keberadaan hand sanitizer tetap dibutuhkan pada masa pandemi seperti sekarang ini karena dapat 
digunakan pada saat bepergian di mana kita tidak menemukan tempat untuk mencuci tangan dengan menggunakan sabun.

Mahasiswa Unbaja pada KKM 2020 ini telah membuat hand sanitizer dari bahan alami yaitu lidah buaya. Diharapkan proses pembuatan hand sanitizer yang diunggah mahasiswa ke beberapa media sosial dapat dilihat atau diakses masyarakat luas. Bagi masyarakat yang menekuni pembuatan hand sanitizer ini dapat meningkatkan pendapatan (income) karena pangsa pasar masih cukup bagus. Apalagi bahan dasar dari hand sanitizer ini adalah bahan alami yaitu lidah buaya. Lidah buaya (aloe vera) aman untuk dipergunakan sebagai obat luar maupun dikonsumsi sebagai makanan sehat serta mudah dalam membudidayakannya.

Alat dan Bahan

Alat:

1. Pisau

2. Piring

3. Sendok

4. Wadah untuk hand sanitazer

Bahan:

1. $100 \mathrm{ml}$ alkohol dengan kadar minimal $70 \%$

2. $50 \mathrm{ml}$ lidah buaya yang diambil dari 3 lembar daun lidah buaya

3. Menghasilkan $150 \mathrm{ml}$ hand sanitizer

\section{Cara Pembuatan}

Pada proses pembuatan hand sanitizer ini, pertama siapkan bahan dan alat terlebih dahulu, kemudian ambil dan cuci lidah buaya hingga bersih. Setelah bersih, kita kupas dan haluskan lidah buayanya hingga selesai. Setelah itu kita tuangkan ke dalam botol dan campurkaan dengan alkohol secukupnya. Lalu kita kocok dahulu sebelum digunakan. Setelah selesai dikocok, hand sanitizer pun siap untuk digunakan. Sebagai tambahan, fungsi lidah buaya adalah untuk menjaga supaya kulit tangan tetap halus dan lembut walaupun menggunakan alkohol. Untuk lebih lengkapnya, penulis akan memberikan link url untuk melihat video cara pembuatan masker hand sanitizer dari bahan lidah buaya. 


\section{Masker Kain Ramah Lingkungan}

Sama seperti hand sanitizer, penulis juga sangat kesulitan mendapatkan masker di awal Maret 2020. Walaupun barang tersedia, harganya cukup mahal yaitu sekitar Rp. 400.000,00 per kotak untuk masker biasa (surgical mask). Seiring dengan peningkatan pasien yang terkonfirmasi positif, pemerintah terus menghimbau dan meminta kepada masyarakat Indonesia untuk menggunakan masker. Baik itu masyarakat yang sehat maupun yang sedang sakit. Himbauan ini selaras dengan dengan rekomendasi World Health Organization (WHO) dalam mencegah penyebaran COVID-19. Juru Bicara Pemerintah untuk Penanganan Virus Corona, Achmad Yurianto dalam konferensinya, menyampaikan mulai Minggu, 5 April 2020, seluruh masyarakat diminta menggunakan masker saat keluar rumah. Bahkan ini suatu kewajiban bagi masyarakat, karena menurutnya ketika seseorang berada di luar rumah akan ada banyak sekali ancaman penularan virus. Jadi penting bagi seluruh masyarakat untuk menggunakan masker. Beliau menjelaskan masyarakat umum dapat menggunakan masker berbahan dasar kain, sedangkan tenaga kesehatan wajib mengenakan masker bedah atau masker N95 (Tim PKRS RSST, 2020). Salah seorang reporter Kontan.Co.Id yaitu Khomarul Hidayat dan Syamsul Ashar (2020) mengungkapkan bahwa masker kain dapat digunakan untuk mencegah penularan sekaligus mengantisipasi kelangkaan masker yang terjadi di pasar seperti apotek dan toko-toko kesehatan.

Oleh karena pemerintah sudah mengeluarkan himbauan pentingnya menggunakan masker dan masker kain direkomendasikan sebagai salah satu masker yang dapat dipergunakan masyarakat luas, sehingga masyarakat mulai memproduksi masker kain. Seperti diketahui pada masa pandemi covid-10 ini, banyak usaha garmen yang tutup. Seharusnya hal ini tidak perlu terjadi apabila masyarakat yang menekuni usaha garmen segera beralih untuk memproduksi masker kain.

Pada kegiatan KKM 2020 ini, sekelompok mahasiswa UNBAJA juga berperan aktif untuk merespon kebutuhan masyarakat akan masker. Mereka membuat video cara pembuatan masker dari kain dan mengunggahnya ke beberapa media sosial. Seperti produk sebelumnya yaitu balsem dari ekstrak jahe dan hand sanitizer, maka diharapkan juga video pembuatan masker ini dapat diakses masyarakat luas dan menginspirasi mereka dalam mengembangkan usaha pembuatan masker. Dengan demikian masyarakat dapat tetap produktif di masa pandemi dan dapat meningkatkan ekonomi mereka. Berikut akan dijelaskan alat dan bahan serta cara pembuatan masker kain yang menghasilkan 15 pcs masker.

Alat dan Bahan 
Alat:

1. Gunting

2. Alat ukur

3. Mesin jahit

Bahan:

1. Kain 1 meter

2. Tali Karet 1 roll

\section{Cara Pembuatan}

Bagi orang yang senang atau punya keahlian menjahit, maka proses pembuatan masker kain ini sangat sederhana dan tidaklah sulit. Adapun proses pembuatan masker kain ini sebagai berikut, Pertama persiapkan kain yang hendak di bentuk menggunakan alat ukur sekitar $30 \mathrm{~cm}$ per 1 pcs masker, setelah itu ukur tali karet $15 \mathrm{~cm}$ di atas dan $15 \mathrm{~cm}$ di bawah. Setelah keduanya sudah di ukur dan di gunting maka kain dan tali di jahit menggunakan mesin jahit. Setelah penjahitan selesai maka akan cek dari hasil jahitan dan siap di gunakan juga di pasarkan

\section{HASIL DAN PEMBAHASAN}

Penulisan artikel ini berdasarkan semua kegiatan yang dilakukan oleh mahasiswa selama mengikuti Kuliah Kerja Mahasiswa (KKM) 2020. Seperti yang sudah diuraikan pada sub bab sebelumnya, maka kegiatan yang dilakukan oleh mahasiswa dapat dibagi menjadi kegiatan per individu dan kegiatan per kelompok. Kegiatan per individu adalah membuat video sesuai dengan tema KKM dan kegiatan per sub kelompok membuat proposal yang sesuai dengan skema Program Kreatifitas Mahasiswa, yang kebetulan dalam kelompok 10, mahasiswa lebih memilih jenis PKM Kewirausahaan.

Dari sejumlah kegiatan tersebut, terbentuk sejumlah tujuan yang dapat meningkatkan produktifitas masyarakat yang positif. Selain itu, produk yang dibuat oleh mahasiswa seperti balsem ekstrak jahe, hand sanitizer dan masker dapat meningkatkan kesehatan dan daya tahan tubuh bagi masyarakat di tengah pandemi covid-19 seperti sekarang ini. Berikut dijelaskan beberapa hal yang menjadi tujuan positif dari sejumlah kegiatan mahasiswa KKM: 
1. Menumbuhkan kemampuan usaha kecil dan menengah menjadi usaha tangguh dan mandiri.

2. Meningkatkan peran usaha kecil dan menengah dalam pembangunan daerah, penciptaan lapangan kerja, pertumbuhan ekonomi dan khususnya meningkatkan produktifitas masyarakat di tengah pandemi covid-19.

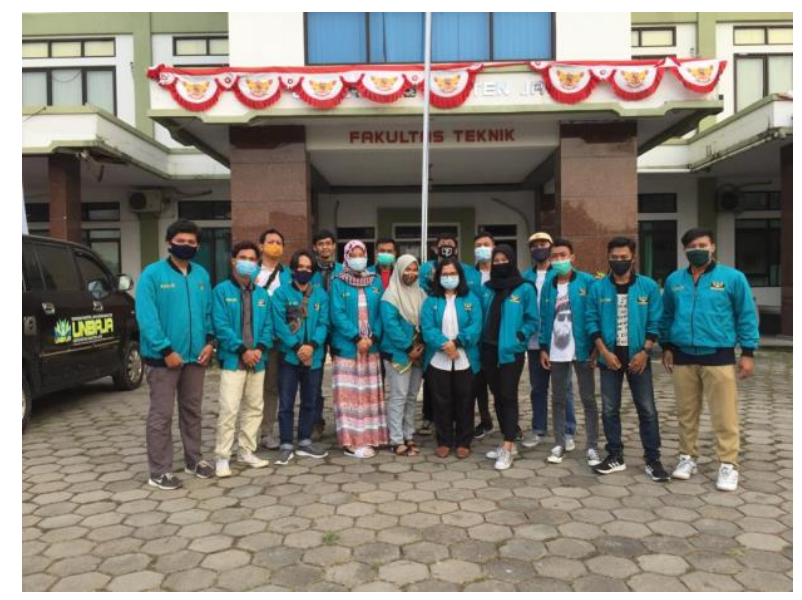

\section{Gambar 3. Dosen Pembimbing Bersama dengan Mahasiswa KKM UUBAJA}

Walaupun pada kegiatan ini dilarang untuk terjun secara langsung ke masyarakat (seperti layaknya keadaan normal), akan tetapi kebijakan masih memperbolehkan mahasiswa untuk bertemu masyarakat dalam jumlah terbatas. Disarankan untuk melakukan kegiatan di lingkungan tempat tinggal mahasiswa dengan tetap memperhatikan dan menaati protokol kesehatan. Tabel berikut menjelaskan tentang realisasi kegiatan mahasiswa yang memuat informasi tentang produk yang dihasilkan, tempat dan jadwal pembuatan.

Tabel 1. Realisasi Kegiatan

\begin{tabular}{|c|l|l|l|}
\hline No & \multicolumn{1}{|c|}{ Nama Produk } & \multicolumn{1}{|c|}{ Tempat Pembuatan } & \multicolumn{1}{c|}{ Pelaksanaan } \\
\hline 1 & $\begin{array}{l}\text { Masker Kain Ramah } \\
\text { Lingkungan }\end{array}$ & $\begin{array}{l}\text { Kp.Tirtalaya Banten Girang Rt 02 Rw 24 } \\
\text { Kota Serang Banten }\end{array}$ & $\begin{array}{l}\text { Tanggal 08 dan 22 } \\
\text { Agustus 2020 }\end{array}$ \\
\hline 2 & $\begin{array}{l}\text { Hand sanitizer } \text { dari } \\
\text { Bahan Alami }\end{array}$ & $\begin{array}{l}\text { Kp. Tenjo Laut Desa Luwuk kec. Serang kab. } \\
\text { Serang provinsi Banten }\end{array}$ & $\begin{array}{l}\text { Tanggal 15 dan 20 } \\
\text { Agustus 2020 }\end{array}$ \\
\hline 3 & Balsam Ekstrak Jahe & $\begin{array}{l}\text { Kp. Pamarayan Rt 03 Rw 01 Desa } \\
\text { pamarayan kec. Pamarayan kab. Pamarayan }\end{array}$ & $\begin{array}{l}\text { Tanggal 10 dan 17 } \\
\text { Agustus 2020 }\end{array}$ \\
\hline
\end{tabular}


Berikutnya, penulis akan membahas tentang capaian yang diperoleh dari kegiatan KKM dalam bentuk realisasi Program Kerja yang disajikan dalam bentuk tabel.

Tabel 2. Program Kerja

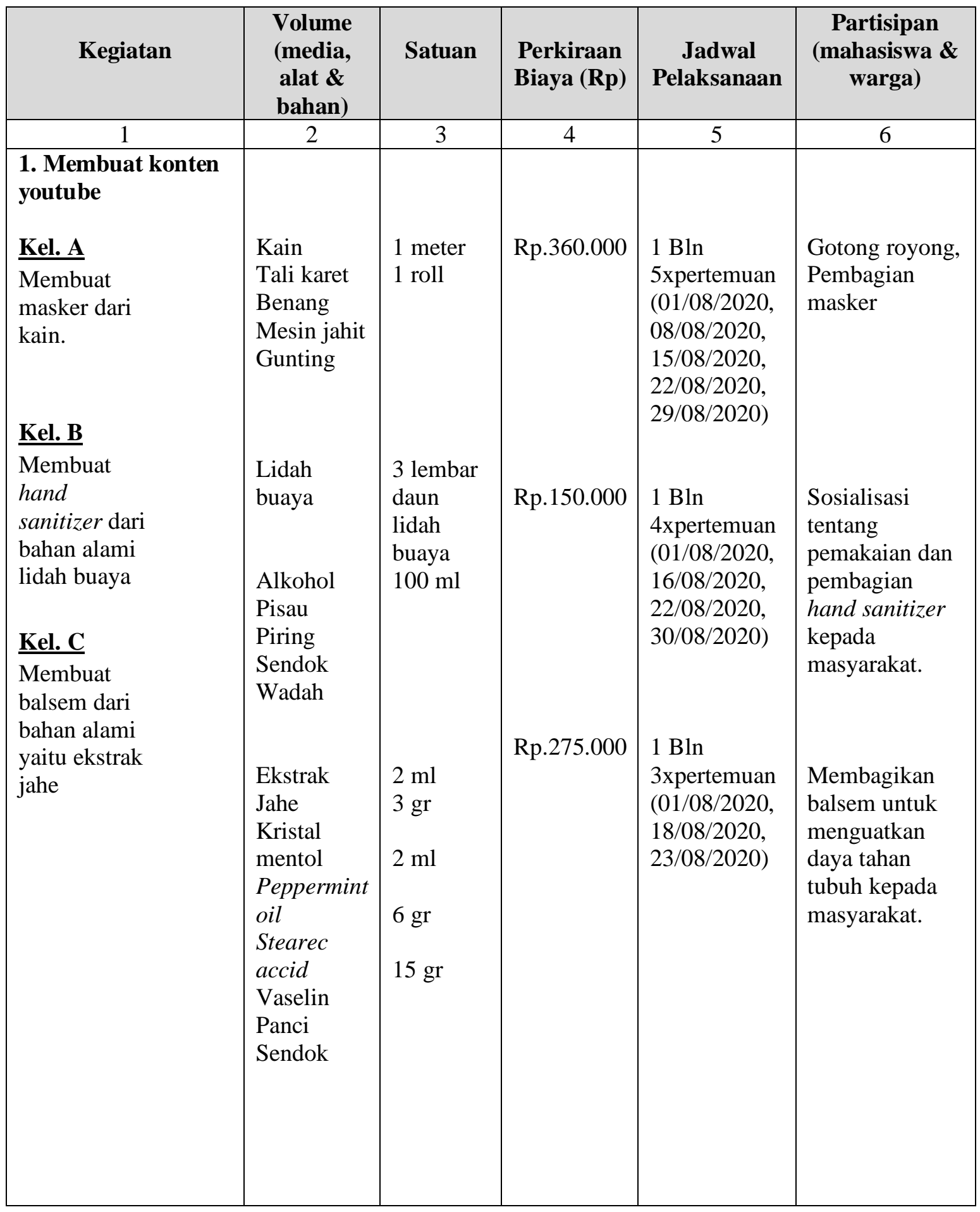




\begin{tabular}{|c|c|c|c|c|c|}
\hline Kegiatan & $\begin{array}{c}\text { Volume } \\
\text { (Media, } \\
\text { alat dan } \\
\text { bahan) }\end{array}$ & Satuan & $\begin{array}{l}\text { Perkiraan } \\
\text { Biaya (Rp) }\end{array}$ & $\begin{array}{c}\text { Jadwal } \\
\text { Pelaksanaan }\end{array}$ & $\begin{array}{c}\text { Partisipan } \\
\text { (Mahasiswa \& } \\
\text { Warga }\end{array}$ \\
\hline $\begin{array}{ll}\text { 2. } & \text { Melakukan } \\
\text { sosialisasi } \\
\text { aturan } \\
\text { yang ada } \\
\text { pada } \\
\text { protokol } \\
\text { kesehatan } \\
\text { di medsos. }\end{array}$ & $\begin{array}{l}\text { Instagram } \\
\text { Youtube } \\
\text { Facebook }\end{array}$ & $\begin{array}{l}\text { Kuota } \\
\text { internet }\end{array}$ & Rp. 250.000 & $\begin{array}{l}1 \mathrm{~B} \ln =2 \mathrm{X} \\
\text { Pertemuan } \\
(15 / 08 / 2020 \\
23 / 08 / 2020)\end{array}$ & $\begin{array}{l}\text { Mengumpulkan } \\
\text { warga sesuai } \\
\text { dengan } \\
\text { protokol yang } \\
\text { ada misal wajib } \\
\text { memakai } \\
\text { masker ketika } \\
\text { sosialisasi dan } \\
\text { memakai hand } \\
\text { sanitizer }\end{array}$ \\
\hline $\begin{array}{l}\text { 3. Membuat } \\
\text { porposal sesuai } \\
\text { skema PKM }\end{array}$ & $\begin{array}{l}\text { Laptop } \\
\text { HVS } \\
\text { ATK } \\
\text { Kuota } \\
\text { internet }\end{array}$ & & Rp.100.000 & $\begin{array}{l}1 \mathrm{Bln}=10 \mathrm{X} \\
\text { pelaksanaan } \\
\text { (Tanggal } \\
01 / 08 / 20 \\
08 / 08 / 20 \\
\text { 15/08/20, } \\
21 / 08 / 20 \\
25 / 08 / 20 \\
26 / 08 / 20 \\
27 / 08 / 20 \\
28 / 08 / 20 \\
29 / 08 / 20 \\
30 / 08 / 20 \text { ) } \\
\end{array}$ & $\begin{array}{l}100 \% \\
\text { Mahasiswa } \\
\text { KKM } \\
\text { kelompok } 10 \\
\text { berkontribusi } \\
\text { dalam } \\
\text { pembuatan } \\
\text { proposal }\end{array}$ \\
\hline $\begin{array}{l}\text { 4. Melakukan } \\
\text { penyuluhan Tentang } \\
\text { penggunaan masker } \\
\text { kain, hand sanitizer } \\
\text { dan balsem di era new } \\
\text { normal. }\end{array}$ & Pemateri & $\begin{array}{l}\text { Umi } \\
\text { Farisa } \\
\text { dari PMI } \\
\text { Kota } \\
\text { Serang }\end{array}$ & $\begin{array}{l}\text { Rp. } \\
200.000\end{array}$ & $\begin{array}{l}1 \mathrm{~B} \ln 2 \mathrm{X} \\
\text { Pertemuan ( } \\
08 / 08 / 2020 \\
22 / 08 / 2020)\end{array}$ & $\begin{array}{l}\text { Mahasiswa dan } \\
\text { warga }\end{array}$ \\
\hline $\begin{array}{l}\text { 5. Melakukan } \\
\text { uji coba } \\
\text { pelaksanaan } \\
\text { aturan }\end{array}$ & $\begin{array}{l}\text { Masker } \\
\text { Hand } \\
\text { sanitizer } \\
\text { Balsem } \\
\text { ekstrak } \\
\text { jahe }\end{array}$ & & $\begin{array}{l}\text { Rp. } \\
100.000\end{array}$ & $\begin{array}{l}1 \mathrm{~B} \ln 2 \mathrm{X} \\
\text { Pertemuan } \\
(08 / 08 / 20 \\
\text { dan } \\
22 / 08 / 20)\end{array}$ & $\begin{array}{l}\text { Mahasiswa dan } \\
\text { warga }\end{array}$ \\
\hline
\end{tabular}

Penulis juga akan membagikan tiga hasil video yang diunggah ke beberapa media sosial seperti youtube, instagram dan facebook. Dari video tersebut, diharapkan masyarakat luas dapat mengaksesnya, memberi komentar ataupun membagikan lagi ke teman atau kerabat mereka. Link untuk dapat mengakses video tersebut seperti di bawah ini: 
1. Pembuatan masker (jumlah Like $=949$ dan Comment=399; akses pada 31/08/2020) https://youtu.be/Z9_SpTd03xg https://www.instagram.com/tv/CDhiuZdpApX/?igshid=drvwkpcofpnm

2. Pembuatan hand sanitizer (jumlah Like $=117$ dan Comment=271; akses pada 31/08/2020)

https://m.facebook.com/story.php?story fbid=1205287599833856\&id=1000105788

\section{$\underline{13592}$}

\section{https://www.instagram.com/tv/CEHTBYLHaCj/?igshid=1p8551dicnn2g}

3. Pembuatan balsem ekstrak jahe (jumlah Like $=373$ dan Comment=731; akses pada $31 / 08 / 2020)$

https://youtu.be/f-cyDyv5XYg

https://www.instagram.com/tv/CDwDrecJpuo/?igshid=obn9bcytha7k

\section{Dampak dan Manfaat}

Berikut akan dijelaskan mengenai dampak dan manfaat dari setiap kegiatan yang dilakukan mahasiswa. Secara umum dampak positif dari kegiatan mahasiswa dalam mengikuti KKM 2020 yaitu dapat dijadikan peluang bisnis untuk meningkatkan pendapatan. Bahan yang diperlukan untuk menghasilkan produk seperti balsem, hand sanitizer serta masker juga sederhana dan mudah diperoleh. Khusus untuk balsem ekstrak jahe, belum diuji coba di laboratorium akan tetapi pada saat diuji coba pada lansia terdapat penurunan skala nyeri dan pegal badan. Dari segi manfaat maka baik masker, hand sanitizer maupun balsem ekstrak jahe sangat berguna bagi masyarakat khususnya di masa pandemi covid-19 untuk melindungi diri dari paparan virus corona serta meningkatkan daya tahan tubuh.

\section{KESIMPULAN}

Kesimpulan kegiatan KKM 2020 adalah sebagai berikut:

1. Pelaksanaan KKM 2020 memberikan kesempatan kepada mahasiswa untuk dapat membagikan pengetahuan mereka kepada masyarakat luas dalam hal membuat produk yang dapat bermanfaat bagi perlindungan tubuh di masa pandemi covid-19.

2. Kegiatan KKM 2020 dapat memberikan kontribusi yang lebih luas lagi kepada masyarakat dalam hal meningkatkan pendapatan (income) usaha kecil dan menengah dengan menekuni bidang usaha untuk menghasilkan produk yang sangat dibutuhkan masyarakat baik di Indonesia maupun di seluruh dunia sekarang ini seperti masker, hand sanitizer dan balsem penghilang nyeri dan pegal tubuh. Hal ini 
sesuai dengan program yang ditetapkan panitia KKM yaitu dilaksanakan dengan skema KKM Program Kreativitas Mahasiswa (KKM-PKM)

3. Sesuai dengan tema KKM 2020, maka secara keseluruhan dapat disimpulkan bahwa kegiatan KKM 2020 mempunyai kontribusi untuk dapat meningkatkan produktifitas masyarakat di tengah covid-19.

\section{DAFTAR PUSTAKA}

Indonesia, R. (2012). UU RI Nomor 12 Tahun 2012 Tentang Pendidikan Tinggi.

Kemendikbud. (2020). Buku-Pedoman-PKM-2020.

Noor, I. H. (2010). Penelitian dan Pengabdian Masyarakat pada Perguruan Tinggi. Jurnal Pendidikan Dan Kebudayaan, 16(3), 285. https://doi.org/10.24832/jpnk.v16i3.462

Pibriani, E. (n.d.). Balsem Jahe Stick. PKMK-2-12-1. https://pdfs.semanticscholar.org/c9a7/a33e81f220a3c9333566a1f506d2c58442d 7.pdf

Sukmayadi, A. E., Sumiwi, S. A., Barliana, M. I., \& Aryanti, A. D. (2014). The Immunomodulatory Activity of Ethanol Extract of Tempuyung Leaves (Sonchus arvensis Linn.). Indonesian Journal of Pharmaceutical Science and Technology, 1(2), 65-72. https://doi.org/10.15416/ijpst.v1i2.7515

Wulansari Sisca, Fitri Aida Sari, Budi Mulyati, Ely Nuryani, D. K. (2020). Panduan Teknis Pelaksanaan KKM. 5.

Alit Kurniawan. 2018. Jahe Ternyata Memiliki Manfaat untuk Meredakan Pegal Otot. https://www.tribunnews.com/tribunners/2018/11/15/jahe-ternyata-memilikimanfaat-untuk-meredakan-pegal-otot, diakses pada 01 September 2020 pukul 21.30 .

Gazali Solahuddin. 2020. Cegah Virus Corona Covid-19 Mengandalkan Hand Sanitizer Salah Kaprah, Justru Bisa Berdampak Sebaliknya. https://health.grid.id/read/352048532/cegah-virus-corona-covid-19mengandalkan-hand-sanitizer-salah-kaprah-justru-bisa-berdampaksebaliknya?page=all, diakses 02 September 2020 pukul 12:21.

Tim PKRS RSST. 2020. Pentingnya Sebuah Masker Saat Pandemi Covid-19. https://rsupsoeradji.id/pentingnya-sebuah-masker-saat-pandemi-covid-19/, diakses 02 September 2020 pukul 13.20.

Khomarul Hidayat, Syamsul Ashar. 2020. Yuk mengenal jenis masker rekomendasi WHO untuk melawan virus corona. https://kesehatan.kontan.co.id/news/yuk- 
P-ISSN : 2686-6447

Jurnal ABDIKARYA

E-ISSN : 2715-6605

Volume 2, No. 2, Oktober 2020

mengenal-jenis-masker-rekomendasi-terbaru-who-untuk-melawan-virus-

corona?page=all, diakses 03 September 2020 pukul 13:14. 